K A UKO KYYR Ö

\title{
Viipurin Suomalainen Kirjallisuusseura ja Aleksis Kivi
}

Aleksis Kiven nimi esiintyy ensimmäisen kerran Viipurin Suomalaisen Kirjallisuusseuran säilyneissä asiakirjoissa toukokuun 18 p :nä 1868 pidetyn Seuran kokouksen pöytäkirjan neljännessä pykälässä, josta luemme seuraavan merkinnän:

"Herra vara-esimies luki Seuralle kirjeen, jossa ylioppilas Alexis Kivi $^{1}$ tarjoaa Seuran ostettaviksi ja painatettaviksi seuraavaa kolme yksinäyttöistä näytelmää: 'Sankarintyö', 'Lea' ja 'Jäähyväishetki'. Tämän kuultua päätti Seura sihtierinsä kautta kysyä hra Kiveltä, mikä on hinta kullakin käsikirjoituksella, ja saapiko niissä kielenmuutoksia tehdä, sekä voivatko olla täällä tulevaan syksyyn asti tutkittavina; ja saada ne niin aikaseen kuin mahdollista tutkituiksi, valittiin myös nyt jo herrat E. Olsoni, Fr. Polén ja R. Mallenius tutkimaan mainituita käsikirjoituksia, joiden on niistä miete annettava _ _ - .."

Näytelmien nimistä vain L e a n tunnemme Kiven kootuista teoksista. Palaamme tähän seikkaan tuonnempana, sillä sitä ennen on mielestämme selvitettävä kolme kohtaa, jotka pöytäkirjanotteesta herättävät uteliaisuuttamme.

Ensiksi haluaisimme tietää, miksi Kivi kääntyi näytelmineen juuri Viipurin Suomalaisen Kirjallisuusseuran eikä jonkun muun kustantajan puoleen, jotka paikallisesti olisivat olleet häntä lähempänä. Syitä siihen on varmasti useampiakin kuin se, jonka J. V. Lehtonen esittää, nimittäin että Seuran puheenjohtajana oli tähän

\footnotetext{
1 Sihteeri, maisteri Axel Gabriel Corander, kirjoittaa ristimänimen toisella kertaa Aleksis. Nimien oikokirjoitukseen nähden hän muutenkin näyttää olleen varsin suurpiirteinen; oman sukunimensä hän alkaa milloin $\mathrm{C}: 11$ ä, milloin $\mathrm{K}: 11 \mathrm{a}$.
} 
aikaan Viipurin kirkkoherra Mortimer Forstén, joka aikaisemmin oli ollut Nurmijärven kirkkoherrana ja jota Kivi niinmuodoin piti vanhana tuttavanaan. ${ }^{2}$ Kivellä oli, kuten tunnettua, ollut suuria vaikeuksia etsiessään kustantajia aikaisemmille teoksilleen. $\mathrm{N}$ u $\mathrm{m}$ m i su utarit ja Kanervalan hän oli julkaissut omalla kustannuksellaan, ja eritoten viimeksi mainitun huono myyntimenestys ei kehottanut uhkayritystä jatkamaan. Runoilijan suhteet helsinkiläisen Suomalaisen Kirjallisuuden Seuran johtomiehiin eivät olleet juuri sydämelliset. Sensijaan hänen suosijallaan Julius Krohnilla oli miellyttäviä kokemuksia lkirjallisesta yhteistyöstä Viipurin Suomalaisen Kirjallisuusseuran kanssa. Mainittu seura oli jo yli kahdenkymmenen vuoden ajan harjoittanut varsin huomattavaa kustannustoimintaa, ja äskettäin se oli ottanut näytelmien julkaisemisen kansansivistysohjelmaansa. Seuran N ä y t el m i ä-sarjan ensimmäinen vihko oli tänä'ajankohtana jo ilmestynyt, ja Kivi lienee tarkoittanut näytelmänsä sarjan tekeillä olevaan toiseen vihkoon.

Toiseksi pistää silmäämme Kivelle näytelmien suhteen osoitettu tiedustelu, "saapiko niissä kielenmuutoksia tehdä". Viipurin seuralle tarjottiin vuosien varrella suuri joukko erilaisia käsikirjoituksia kustannettaviksi, ja niiden kieliasua jouduttiin useimmissa tapauksissa korjailemaan, mutta Kiven tapausta lukuunottamatta en ole kertaakaan havainnut, että kielenkorjailusta on tiedusteltu tai siitä edes puhuttu etukäteen, siis ennen Seuran asettamien tarkastajien antamaa lausuntoa. Tämä seikka antanee syytä otaksua, että August Ahlqvistin koko 1860-luvun ajan teroittama käsitys Aleksis Kivestä kelvottomana suomen kielen käyttäjänä oli vuosikymmenen lopulla levinnyt jo laajoihin kirjallisiin piireihin.

Kolmas huomiota herättävä seikka on Seuran tutkijalautakunnan kokoonpano. Koulunopettaja, tohtori Fredrik Polénin voimme kyllä hyväksyä Kiven arvostelijaksi; hänen teoreettiset opintonsa, suomen kielen harrastuksensa, oma kirjallinen työnsä ja kirjallisuuden ymmärryksensä antavat mielestämme hänelle tuon oikeuden. Mutta "varamaakamreeri" Olsonin ja "kauppakonttorista" Malleniuksen sijalla näkisimme mielellämme asiantuntevammat henkilöt. Tosin he molemmat olivat äidinkieleltään suomalaisia ja samoin molemmat hieman harjoittaneet sanomalehtikynäilyä ja harrastelijarunoutta,

${ }^{2}$ J. V. Lehtonen, Nurmijärven poika, s. 80 . 
mutta jälkiviisaus näkee kohtuuttomuutena, että he lausurat tuomionsa mestarin kynänjäljistä. Varmasti Seuralla olisi ollut sopivampiakin henkilöitä Olsonin ja Malleniuksen sijaan, mutta kuitenkin on vaikeaa syyttää Seuraa asiantuntijoiden valinnasta, sillä käsikirjoituksia tarjottiin kustannettaviksi näinä vuosina nïn runsaasti, että Seura pystyi selviytymään niiden arvioimisesta vain siten, että kukin sen toimivista jäsenistä vuorollaan otti tehtävän vastaan.

Tutkijalautakunta sai työnsä valmiiksi Seuran lokakuun 6 p:nä 1868 pidettyyn kokoukseen ja antoi siellä Kiven tarjoamista näytelmistä seuraavan arvostelun pöytäkirjaan merkittäväksi :

"Jäähyväishetki. Tässä on keskustelu hyvä ja henkilöiden mieliluonteet myös hyvästi kuvatut, mutta kertomus kokonaan pitkämaista (sic!), kun ei ole tapausta mitään koko aikana; se tarvitseisi siis tapauksia, kunnolliseksi tullakseen.

Sankarintyö on kiitettävä sekin, sillä kuvaus siinä on Suomen kansasta otettu, mutta taiteellisuutensa puolesta on teos puolitekoinen, kun kuvauksen lopullinen selviäminen siinä ihan puuttuu. Lukija ei saa vastausta kuka voittaa, tytön hellä rakkausko vai hänen isänsä selvä ymmärrys ja vaka kokemus, eikä myöskään tule selville, miksi Heribert-parooni muuttuu. Pait sitä, niin paroonin ja isänki mieliluonteet ovat loppupuolella raukeammasti kuvatut kuin alussa. Tämä näytelmäkappale ei siis tyydytä lukijaa eikä näkijääkään. Siihen olisi pantava enemmän taiteellisuutta, paroonin ja isän mieliluonteet olisivat parannettavat ja isän vatsatauti ihan jätettävä pois, sekä koko teos jatkettava 2 : $^{\text {sel1a }}$ näytöksellä, missä kuvauksen loppu selviäisi.

Lea on kaikin puolin muuten otollinen pait että muutamat yksinpuheet (eli monologit) olisivat lyhennettävät ja kieli yleiseen varotellen parannettava ja korjailtava."

Tämän suosituksen perusteella Seura päätti ostaa L ean ja maksaa siitä $25 \mathrm{mk}$ painoarkilta. Kuitenkin oli L e a a $\mathrm{n}$ - edelleen pöytäkirjan mukaan —

"Seuran toimella tehtävä ne parannukset, mitä tutkijakunta esittelee, jota vastoin ne molemmat toiset näytelmä-kappaleet ovat hra Aleksis Kivelle takaisin lähetettävät parannettaviksi sen mukaan kuin tutkijakunta on esitellyt, ja lähettäköön sitten hra Kivi, jos niin tahtoo, ne parannettuina tänne uudestaan tutkittaviksi".

Ilmeisesti siis Lea jäi Viipuriin ja Jäähyväishetki ja $\mathrm{S}$ a n k a ri nt y ö palasivat takaisin Siuntion Fanjunkarsiin. Jää- 
hyväishetki löytyi myöhemmin runoilijan jälkeenjättämistä papereista ja julkaistiin Kiven Valittujen Teosten toisessa niteessä, v. 1878 nimellä L e ja Li in a, joka alun perin oli ollut näytelmän työnimenä, kuten Kiven kirjeestä Bergbomille vưoden alussa 1868 käy ilmi. Sankarintyö sensijaan on jäljettömiin kadonnut. Millainen näytelmä on ollut, onko kysymyksessä ollut huvinäytelmä vai pikku draama, siitäkään emme tiedä mitään, koska, kuten Koskenniemi huomauttaa, Viipurin Suomalaisen kirjallisuusseuran pöytäkirjaan viety lausunto on laadultaan pikemmin arvosteleva kuin selostava. ${ }^{3}$ Ehkäpä vahinko kuitenkaan ei ole suuren suuri; runoilijalla itselläänkään ei näytä Sankarinty östä olleen erikoisen korkeaa käsitystä. ${ }^{4}$

Runoilijan vaikeata taloudellista asemaa ei hänen saamansa tekijäpalkkio, "ostoraha", pystynyt korjaamaan, sillä painetun teoksen laajuudeksi tuli vain hieman kolmatta painoarkkia. Mainittu "ostoraha" oli tuskin oikeassa suhteessa kääntäjille maksettuun palkkioon, $16 \mathrm{mk}$ painoarkilta, ja kielentarkastajien palkkioon, $4 \mathrm{mk}$ painoarkilta, mutta sellainen näyttää Seuran taksa olleen näinä vuosina suomenkielisten alkuperäisteosten kirjoittajille.

Erikoisesti pistää silmäämme se seikka, että tutkijakunnan suosittelemat L ean parannukset ja korjaukset oli tehtävä "Seuran toimella”. Mitään merkkejä ei ole osoittamassa sitä, että niistä olisi neuvoteltu runoilijan kanssa tai että Kivi edes olisi nähnyt L ea n käsikirjoitusta näiden "parannusten" jälkeen, siis ennen näytelmän joutumista painoon. Kuka Seuran puolesta on tämän asian hoitanut, se ei käy asiakirjoista ilmi, mutta tavallisesti tällaiset tehtävät uskottiin Seuran tarmokkaalle sihteerille Axel Gabriel Coranderille, joka näinä vuosina toimi koulumestarina Viipurissa ja jolla suomen kielen lauseopin tekijänä ja uutterana sanomalehtimiehenä oli laajemmallakin kuin vain Seuran piirissä mainetta taitavana suomen kielen tuntijana ja käyttäjänä. A. G. Corander oli Viipurin Suomalaisen Kirjallisuusseuran sihteerinä vv. 1856-75. Hänen kirjoittamansa pöytäkirjat, vuosikertomukset ym. asiakirjat ovat edelleen sodan tuhoilta ja tulelta säilyneinä. Niiden tarkastelija ei tarvitse paljoa asiantuntemusta voidakseen epäämättömästi todeta, että

\footnotetext{
${ }^{3}$ V. A. Koskenniemi, Aleksis Kivi, s. 134.

${ }^{4}$ Aleksis Kiven Kootut Teokset IV, s. 415.
} 
Coranderin kielenkäyttöön hänen itäsuomalainen murrepohjansa painoi selvän leiman. Erikoistutkimus voisi kenties selvittää, missä määrin Viipurissa - Coranderin tai muiden Viipurin Suomalaisen Kirjallisuusseuran toimihenkilöiden taholta - L e a n tekstiin on puututtu ja mestarin kieltä "paranneltu", kuten tutkijalautakunta ja pöytäkirja edellyttävät, toisin sanoen onko Leass a havaittavissa viipurilaista Eskon puumerkkiä.

Joulukuun ensimmäisenä 1868 pidetyn kokouksen pöytäkirjasta. näemme, että L e a sta on otettu 500 kappaleen painos.

Vuoden 1869 tammikuun 9 p:nä pidetyn kokouksen pöytäkirjassa on säpsähdyttävä maininta, että eräät seuranäytelmien esittäjät ovat - malttamatta odottaa L e a $n$ ilmestymistä painosta - pyytäneet saada lainata käsikirjoitusta näytelmäharjoituksiinsa. Emme aikaisemmin emmekä myöhemmin tapaa Viipurin Suomalaisen Kirjallisuusseuran papereissa tämänkaltaista merkintää minkään muun teoksen kohdalta. Näin ollen voinemme olettaa, että Kiven odotettavissa oleva näytelmä herätti ainakin uteliasta odotusta ja että runoilijan nimi ja maine eivät olleet kirjallisen yleisön keskuudessa aivan niin tuntemattomat kuin usein on haluttu uskoa. Seuralla ei ollut mitään käsikirjoituksen lainaamista vastaan. Se ehto kuitenkin asetettiin, että käsikirjoitusta ei tietenkään saanut hävittää ja että sen lainaaminen ei saanut hidastuttaa painatusta. Lainaajien joukossa oli mm. Kaarlo Bergbom, joka valmisti L e a n esityksen Uudessa Teaterissa toukokuun $10 \mathrm{p}$ :nä 1869. ${ }^{5}$ Samana vuonna L e a sitten ilmestyi Viipurin Suomalaisen Kirjallisuusseuran Nä y telmi ä-sarjan toisessa vihossa rinnallaan perin avuton Holbergin mukaelma A rabial a is t a p u lveri a. Viimeksi mainitusta näytelmästä tutkijakolmikolla Olsoni-Polén-Mallenius oli pelkkää hyvää sanottavanaan.

Kokouksessa marraskuun 13 p:nä 1869 Seuran esimies luki dosentti Julius Krohnin lähettämän kirjeen, jossa hän tarjosi Seuran kustannettavaksi "hra A. Kiven tekemän S e its emän W elj e st ä nimisen kertomuksen". Kun kokous ei ollut päätösvaltainen, asiasta voitiin vain keskustella, mutta ei tehdä päätöstä. Koska Krohn kuitenkin pyysi pikaista vastausta tarjoukseensa, annettiin

5 Lehtonen, emt. ss. 300-301. 
vastaus epävirallisesti. Siinä varojen puutteeseen vedoten tarjous kohteliain sanakääntein torjuttiin.

Silmäys Seuran tileihin osoittaa, ettei varojen puute suinkaan ollut tekaistu veruke. "Suuret nälkävuodet" hieman aikaisemmin olivat olleet myös hengen nälkävuodet ja merkinneet Seuran kustannustoiminnalle ja kirjakaupalle sellaista iskua, josta ne eivät enää koskaan ennalleen toipuneet. Leivän loppuessa oli kaikkinainen taloudellinen toiminta maassamme täydellisesti tyrehtynyt. Ensimmäisten joukossa sen olivat joutuneet kokemaan kirjakauppiaat. Seuran liiketoimintaa hoitelevat lehtorit ja pastorit olivat varmaankin liian tottumattomia ja hyväuskoisia liikemiehiksi, ja.niin Viipurin Suomalainen Kirjallisuusseura kärsi kirjakauppojen vararikoissa niin suuria luottotappioita, että niitä oli mahdoton myöhemmin korvata.

Helmikuun 3 p:nä 1970 pidetty vuosikokous oli edellisen epävirallisen kokouksen kanssa yhtä mieltä s e it s e män W eljeks e n kustantamisesta. Asiasta ilmoitettiin Julius Krohnille. Tämä. on viimeinen merkintä Aleksis Kiven elämäntyöstä Viipurin Suomalaisen Kirjallisuusseuran asiakirjoissa.

\section{Kauko Kyyrö: The Finnish Literary Society of Viipuri and Aleksis Kivi}

The Finnish Literary Society of Viipuri had been carrying on quite an extensive publishing activity for more than two decades when, in the spring of 1868, Aleksis Kivi, who continually had difficulties with the publication of his works, turned to this society and offered it the right to publish his three plays. "Sankarintyö", "Lea", and "Jäähyväishetki". Of these three, only one, "Lea", was accepted by the Society, and even this was on condition that the Society be allowed to make some improvements and corrections not only in the structure of the play, but particularly in its language. The present writer leaves it to the experts to decide whether there are any characteristics of the eastern dialect of Finland to be found in the language of the play which could be traced back to the revision of the play by the Society. This is very probable because the revision was in all likelihood the work of A. G. Corander, in whose use of language the influence of the eastern dialect is quite evident. One of the two rejected plays, "Jäähyväishetki", was published posthumously under the title "Leo ja Liina", while the other, "Sankarintyö", has disappeared leaving no trace whatever.

At the end of the following year Kivi offered his novel "Seven Brothers" to the Society for publication, but the offer was rejected. 